\title{
非定常流における砂州の数値解析 NUMELICAL SIMULATION OF SAND BARS UNDER UNSTEADY FLOW
}

\author{
横山洋 1 ・渡邊康玄 2 ・清水康行 ${ }^{3}$ \\ Hiroshi YOKOYAMA, Yasuharu WATANABE and Yasuyuki SHIMIZU
}

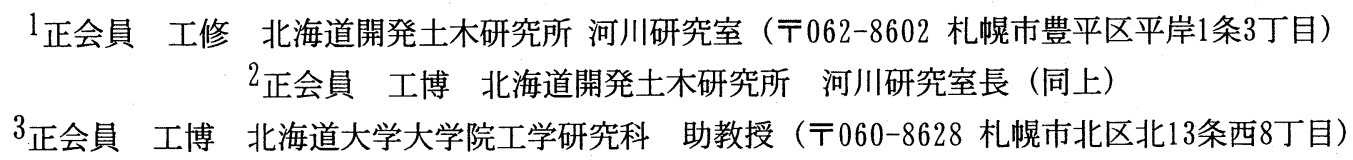

Sand bars in rivers have important effects on river meandering, which cause change of flow and disasters in rivers. There are a lot of studies on bars under steady flow. But unsteady flow (ex. artificial flood) has been considered to restore river environment. It has become more important to predict bed topology under unsteady flow.

In this paper, we calculate changes in riverbed by using 2-D shallow water equation model. The points of this simulation are boundary condition and shape of flood wave. Periodic boundary condition was applied to unsteady flow analysis. We compare with the result of numerical simulation and experiment results. Knowledge on boundary condition in the simulation can be gotten in this research.

Key Words : numerical simulation, alternate bars, unsteady flow, 2-D shallow water equation model

\section{1. 序論}

実河川には水理条件，河道形状に応じて砂州等の河床 波が形成される. 砂州形状は河川の流れを蛇行させる大 きな要因であり, 河道変遷及び河岸の被災と深く関係し ている. また近年河道内の砂州の固定化ならびに樹木繁 茂等が治水上の問題となっており, 河道管理において砂 州の挙動を把握することは今後の河道計画を行う上で重 要な課題である.

交互砂州に関する研究は現地調査, 水埋実験, 埋論解 析, 数值計算ともに従来から数多くなされ，その特性も かなり明らかにされてきている. 例えば黒木·岸1)は実験 值をもとに中規模河床形態の領域区分を行っており, 単 列砂州, 複列砂州の発生条件を述べている. 清水 ${ }^{2}$ (は実 験及び実河川を対象として河床変動を数值解析により再 現している.

ところで砂州に関する既往の研究の多くは, 定常流下 での挙動を検討したものである. 定常流下の中規模河床 形態区分は数多くの研究が行わ机ている. しかし非定常 流れでは河床形状はその瞬間の水理量のみで決まるので はなく, 河床の変化履歴も影響するため, 定常流での河
床形態区分とは異なる挙動を示す．近年ダム等からの計 画的な放流による河川の流況再生を目的とした人工洪水 がわが国でも検討が始まるなど, 河道の水位・変化に着 目した流れの非定常性を考慮した河床形態の把握は重要 性を増してきている.

非定常流における交互砂州の研究例をあげると, Tubino $ら^{3}$ は非定常流下の交互砂州の形成について形成 限界領域での非線形解析を行っている. また三輪ら4は 連続的な流量変化の場合は，一定流量の場合とは異なる 挙動を示すことを実験により明らかにしている. しかし 実験は様々な条件下で多くのケースを実施するのは困難 であり, 理論解析は限られた条件下での解しか得ること ができない，そのため実河川の河床変動を再現できる非 定常流数值計算モデルを構築することは, 交互砂州の研 究を行う上で有用な検討手段となる.

本研究は, 渡邊らの非定常流での直線移動床水路実験 5)を対象に，2次元浅水流モデルによる再現計算を行った. 計算結果を実験結果と比較し, 河床形状及び平面流況を 検証することにより、計算モデルの妥当性を評価した. また計算結果より非定常流下での河床形状の変遷につい て考察を行ったものである. 


\section{2. 計算手法}

流れの基礎式は非定常項を含む2次元浅水流方程式で ある. 運動方程式は移流項とそれ以外の項に分離して解 いており，移流項には清水らりによるCIP法を用いた。

底面摩擦係数 $C_{f}$ は, 渡邊らの実験結果から得られた 次の式(1)で与えている5).

$$
C_{f}=0.0076\left(\frac{h}{d_{m}}\right)^{0.069}
$$

但し $d_{m}$ : 平均粒径 $(=0.76 \mathrm{~mm}), h$ : 各時刻の代表水 深であり，ここではハイドログラフで与えられる水深を 用いている.

渦動粘性係数 $v_{t}$ は, 以下の式(2)で表す.

$$
v_{t}=\frac{\kappa}{6} U_{*} h
$$

ここで $\kappa$ : カルマン定数 $(=0.4), U_{*}$ : 摩擦速度, $h:$ 水深である.

流砂量式は主流方向には芦田・道上の式, 横断方向に は長谷川の式を用いる.

$$
\begin{gathered}
q_{\hat{s}}=17 \tau_{*}^{1.5}\left(1-\frac{\tau_{*_{c}}}{\tau_{*}}\right)\left(1-\sqrt{\frac{\tau_{*_{c}}}{\tau_{*}}}\right) \sqrt{s g d^{3}} \\
q_{\hat{n}}=-q_{\hat{s}}\left(\frac{h}{r_{s}} N_{*}+\sqrt{\frac{\tau_{*_{c}}}{\mu_{s} \mu_{k} \tau_{*}}} \frac{\partial \eta}{\partial y}\right)
\end{gathered}
$$

ここで, $\tau_{*}$ : 無次元掃流力, $\tau_{*_{c}}$ : 限界無次元掃流力, $s$ : 砂の水中比重(=1.65), $d$ : 砂の粒径, $r_{s}$ : 流線の曲率 半径, $h:$ 水深, $N_{*}$ : Engelundによる定数 $(=7.0), \mu_{s}$, $\mu_{k}$ : 砂の静止及び動摩擦係数 $\left(\mu_{s} \mu_{k}=0.5\right), \quad \eta$ : 河床高 である. 砂の粒径は実験の平均值 $(d=0.76 \mathrm{~mm})$ を用い た. 無次元掃流力は岩垣の式により算出している. また

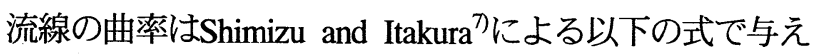
ている.

$$
\frac{1}{r_{s}}=\frac{1}{\left(\sqrt{u^{2}+v^{2}}\right)^{3}}\left[u\left(u \frac{\partial v}{\partial x}-v \frac{\partial u}{\partial x}\right)+v\left(u \frac{\partial v}{\partial y}+v \frac{\partial u}{\partial y}\right)\right]
$$

\section{3. 計算条件}

計算は渡邊らの実験条件に合わせ，水路幅 $30 \mathrm{~cm}$ ，勾 配 $1 / 180$ の矩形水路に平均粒径 $0.76 \mathrm{~mm}$ の均一な硅砂を平 坦に敷き詰めた条件で行っている.

非定常流のハイドログラフは継続時間4時間及び8時間 の2ケースである. 本計算では, 実験条件に合わせ式(6) で表される無次元水深ハイドログラフを与えている5).

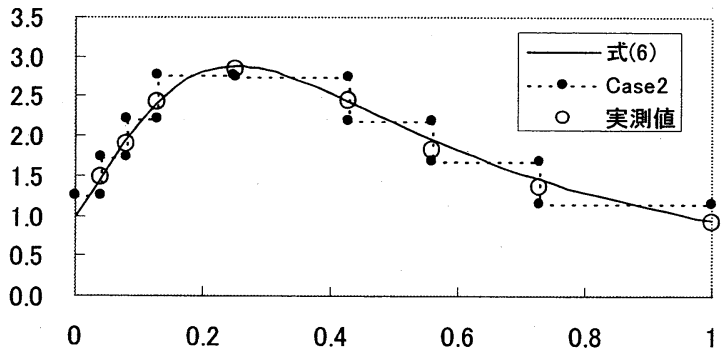

図-1＼cjkstart無次元水深によるハイドログラフ

$$
D_{0}=\left\{\frac{\delta(\tau+\alpha)^{2}}{\tau^{2}+\beta}-\gamma\right\}^{\frac{3}{2}}
$$

ここで $D_{0}$ : 初期水深 $h_{0}$ で無次元化した水深 $\left(D_{0}=h / h_{0}\right) ， \tau:$ ハイドログラフの継続時間 $T$ で無 次元化した時間 $(\tau=t / T), \alpha=0.522, \beta=0.131, \gamma$ $=1.15, \quad \delta=1.03$.

図-1で示される実線は式(6)の関数形を示している. プ ロットされている白抜き点は, 実験における実測時間及 び水深である.

計算值は上下流端での境界条件の設定方法及び計算区 間長により変化すると考えられる．そこで本論では異な る3種類の条件下で計算を行った.

Case1 : 流路長を $10 \mathrm{~m}$ とし，十分に長い流路を想定し て周期境界条件を設定した方法. 流量はハイドログラフ

（図-1実線）に従い連続的に変化する. 計算メッシュは 流下方向に100分割, 横断方向に10分割している. なお 洪水の立ち上がりによる河床変動の違いを検証するため, ハイドログラフは8時間の場合（Case1A）と4時間の場 合（Case1B）の2ケースで行っている.

Case2 : 流路長を $10 \mathrm{~m}$ とし，周期境界条件を設定した 方法. ハイドログラフの変化は連続的ではなく，階段状 に与えている(図-1破線）。

Case3 : 流路長を $20 \mathrm{~m}$ とし，周期境界条件を設定せず に上流端で流量, 下流で水位を与える方法。計算メッ シュは流下方向に200分割, 横断方向に10分割している. 本計算では式(6)のハイドログラフに従い, 代表水深 $h_{m}$ を次のように定める.

$$
h_{m}=h_{0} \times D_{0}
$$

ここで $h_{0}$ : 初期水深, $D_{0}:(6)$ で与えられる無次元水 深. 底面摩擦係数 $C_{f}$ は式(7)で求めた $h_{m}$ を式(1)に代入 して得られる. また代表流速 $u_{m}$ は $h_{m}$ 及び $C_{f}$ を用いて式 (8)で表す.

$$
u_{m}=\frac{1}{n_{m}} h_{m}{ }^{2 / 3} i^{1 / 2}
$$

$$
C_{f}=\frac{g n_{m}{ }^{2}}{h_{m}{ }^{1 / 3}}
$$


表-1 計算条件

\begin{tabular}{|l|l|l|l|l|}
\hline & $\begin{array}{l}\text { 流路長・境界 } \\
\text { 条件 }\end{array}$ & ハイドロ & $\begin{array}{l}\text { ハイドロ } \\
\text { 継続時間 }\end{array}$ & $\begin{array}{l}\Delta \mathrm{t} \\
(\mathrm{sec})\end{array}$ \\
\hline Case1A & $\begin{array}{l}10 \mathrm{~m} \cdot \text { 周期境 } \\
\text { 界条件 }\end{array}$ & 式 (6) & 8 時間 & 0.01 \\
\hline Case1B & $\begin{array}{l}10 \mathrm{~m} ・ \text { 周期境 } \\
\text { 界条件 }\end{array}$ & 式 (6) & 4時間 & 0.01 \\
\hline Case2 & $\begin{array}{l}10 \mathrm{~m} ・ \text { 周期境 } \\
\text { 界条件 }\end{array}$ & 階段状 & 8 8時間 & 0.005 \\
\hline Case3 & $\begin{array}{l}\text { 20m・上流で } \\
\text { 流量、下流は } \\
\text { 等流 }\end{array}$ & 式 (6) & 8 8時間 & 0.01 \\
\hline
\end{tabular}

代表流量 $Q_{m}$ は水路幅を $B$ とし以下の式で表される.

$$
Q_{m}=u_{m} h_{m} B
$$

周期境界条件であるCase1，2では，上流端及び下流端 に代表流速と代表水深を与えている. またCase3では上 流端には代表流量, 下流端には等流条件を与えている.

以上，表-1に計算条件をまとめる.

河床変動については, 全ケースで初期河床は平坦床で 与えている. 微小擾乱を与えるため, 全ケースで上流端 に近い河岸付近の 1 メッシュに高さ $1 \mathrm{~mm}$ のマウンドを設 定している. 流砂量の境界条件は, Case1，2は周期境界 条件を設定している. またCase3では上下流端で動的平 衡条件を満たすようにしている.

\section{4. 計算結果の検証と考察}

\section{(1)渡邊らの実験の再現計算}

次いでケースごとに計算值を実験結果と比較し, 計算 手法の適用性について検証する.

まず，河床変動量について検討する.ここでは計算領 域内の河床高の最大值と最小值の差 $\Delta \mathrm{z}_{\text {max }}$ と実験の河 床波の波高について考察を行う. 図-2は各計算ケースの $\Delta \mathrm{z}_{\text {max }}$ について実時間での変化を示したものである. また図-3は通水8時間のケースについて, 実験值の波高 と計算值の $\Delta \mathrm{z}_{\max }$ を比較したものである.

図-2を見ると, Case1Aは通水開始30分後から $\Delta \mathrm{z}_{\text {max }}$ が顕著に増加し，ハイドログラフのピークである2時間 で最大值をとり, その後徐々に減少している. これは八 イドログラフの波形とほぼ同じ傾向である.Case1Bでは, Case1A 同じく通水開始30分後から $\Delta \mathrm{z}_{\text {max }}$ が急増し, ハイドログラフのピークを過ぎた 1 時間 30 分で最大と なっている. その後 $\Delta \mathrm{z}_{\text {max }}$ はCase1Aと同様に緩やかに 減少していく. 階段状のハイドログラフであるCase2を みると, $\Delta z_{\text {max }}$ は6時間までは流量が連続変化する Case1Aとほぼ同じ值をとっている. しかしその後,

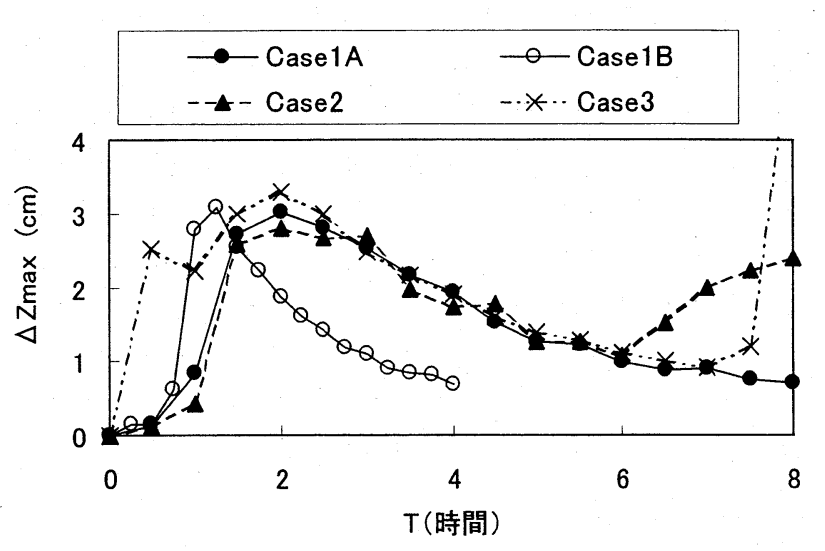

図-2 $\Delta \mathrm{z}_{\max }$ の時間変化

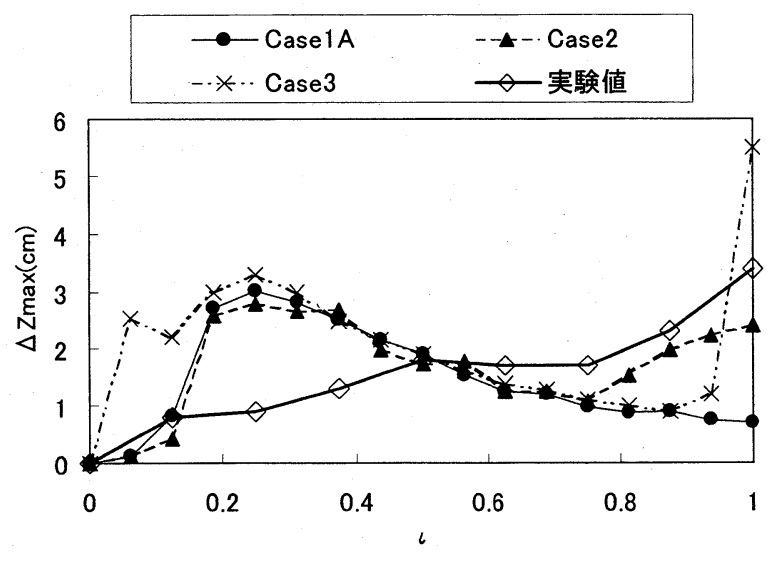

図-3 $\Delta z_{\text {max }}$ の時間変化

$\Delta \mathrm{z}_{\text {max }}$ はCase $1 \mathrm{~A}$ では引き続き減少していくのに対し， Case2ではゆるやかな増加に転じている. 周期境界条件 を設定していないCase3では, $\Delta z_{\text {max }}$ は通水開始直後か ら急増している. その後Case1A, Case2と同様, ハイド ログラフのピークに近い2時間後で最大值をとっている. なお計算終了直前に $\Delta z_{\text {max }}$ が急上昇しているが, これ は局所的に河床が上昇し, 水面上に河床が現れたためと 考えられる。

図-3は通水8時間のケースにおいて, 実験值の波高と 計算值の $\Delta z_{\text {max }}$ を比較したものである. 実験では時間 経過とともに徐々に波高が増加し， $\tau=0.5$ (4時間) で 一旦増加が停止した後, $\tau=0.8$ (6.4時間) から再び増加 に転じている. 最大值は $3.4 \mathrm{~cm}$ である. 一方計算結果は いずれのケースとも, ハイドログラフのピークである $\tau$ $=0.25$ (2時間) 付近で $\Delta z_{\text {max }}$ が最大值をとっている. $\tau$ $<0.5$ では計算による $\Delta \mathrm{z}_{\max }$ は実験值に比べ大きくなって おり, 特に $\tau=0.25$ (2時間) 以前では大きく異なる結果 になっている. また $\tau=0.75$ 以後, Case $2 の \Delta \mathrm{z}_{\text {max }}$ は実験 值と同様の值をとっている. 以上から波高の変遷再現性 については, 通水開始直後はいずれのケースともに計算 值と実験值は異なっている. またピーク後の波高は, Case2が部分的に再現できているといえる.

続いて河床の平面形状について検証する. 図-4は周期 
境界条件であるCase1A，1B，2の河床コンターの時間変 化である. ここでは水路中央部の $4 \mathrm{~m}$ の間を抽出して いる. Case1Aでは $\tau=0.125$ (1時間) では河床はほぼ平 坦なままであるが， $\tau=0.25$ (2時間) では計算全領域に おいて，周期性をもつ河床形状が明瞭に見られるように なる. その後水位が低下するとともに水理量が交互砂州 発生領域に入るため, 計算終了時（ $\tau=1.0: 8$ 時間）の 河床はやや交互砂州の特徵が見られるものとなっている. Case1Bでは $\tau=0.25$ (1時間) ではほぼ平坦な河床である. その後, Case1A と同様, 周期的な河床形状が発達して, 通水完了時では交互砂州にやや近づいた河床形状が見ら れるものとなっている. Case2では通水開始後4時間 （ $\tau=0.5 ）$ まではCase1 と同じく周期的な河床形状が見 られる. その後, 図-4には示していないが河床が水面上 に出たメッシュが両岸に発生し，これが影響して以前の 周期的な河床形状がいったん消滅し，その後Case1A， 1Bに比べ明瞭な交互砂州が出現している.

続いて周期境界条件を設定していないCaes3の河床変 動コンターを図-5に示す.コンターの範囲は, 上流端か ら5mから15mまでの10mの区間である. $\tau=0.0625$ (30 分）で睡に交互砂州が発生している. その後，砂州は消 滅して $\tau=0.25$ (1時間) では短い間隔で交互に洗掘と堆 積が生じている. その後, 河床は下流4～5mを除いて全 体的に平坦化していく， $\tau=0.5$ (4時間) では図中には 河床波はみられないが，さらに下流側には短い波長の周 期的な河床形状が存在している. その後 $\tau=0.75$ （6時 間）では再び交互砂州が見られるようになった.

次いで各ケースの砂州の代表的な波長について検討す る. ここでは以下の式(8)で与えられる無次元波数 $\lambda$ を用 いて検討した.

$$
\lambda=\frac{2 \pi B}{L}
$$

$B:$ 水路幅の $1 / 2(=0.15 \mathrm{~m}), L:$ 蛇行波長である.

図-6は河床波の波数入について, 実験結果と計算值を 比較したものである. なお計算結果の $\lambda$ は, 計算領域内 の周期的な河床形状の平均波長から算出したものである.

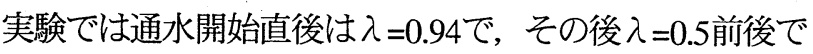
推移している. Case1Aでは， $\tau=0.125$ (1時間) で発生 した波数が通水完了まで一定值を取っている．また階段 状のハイドログラフを設定したCase2では，途中まで Case1 と同じ波数の河床波が生じているが， $\tau=0.75 （ 6$ 時間）以後波長が長くなっている. なお途中 $\tau=0.75 （ 6$ 時間）はプロットしていないが，これは水路全体で明膫 な周期性の河床形状が見られなくなったためである.

Case3では， $\tau=0.0625$ （30分）でまず実験值とほぼ同じ 波長になった後, 急激に波長が短くなっていることがわ かる. その後 $\tau=0.5$ (4時間) を過ぎてから次第に通水 開始直後とほぼ同じ波長の交互砂州が発生している.

ここまでで得られた計算結果について考察を行う.

2次元浅水流計算における周期境界条件について, 中

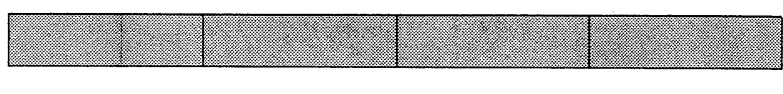

$\tau=0.125$

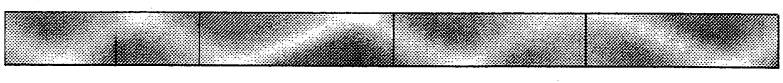

$\tau=0.25$

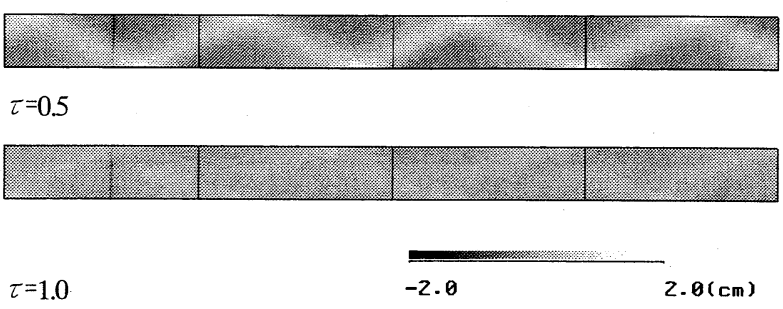

(1)Case1A

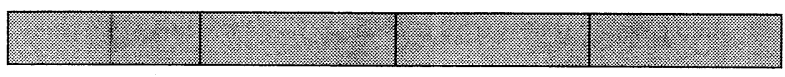

$\tau=0.125$

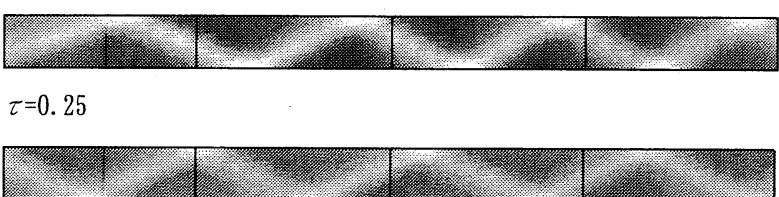

$\tau=0.5$

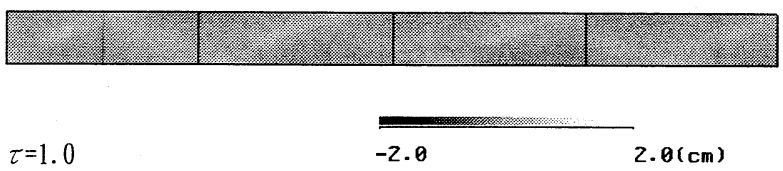

(2)Case1B

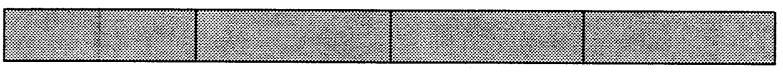

$\tau=0.125$

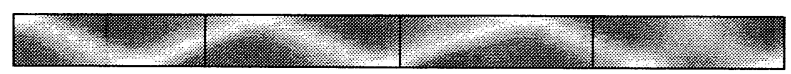

$\tau=0.25$

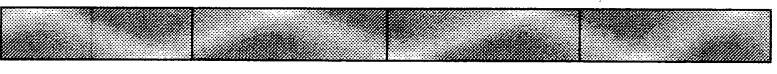

$\tau=0.5$

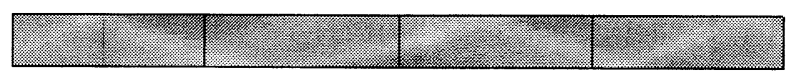

$\tau=0.75$

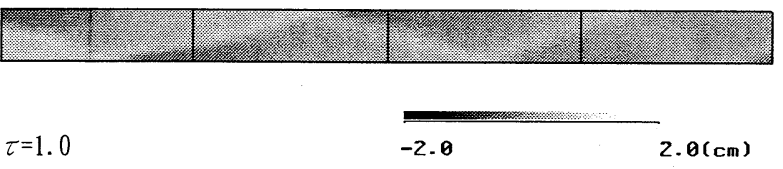

(3)Case2

図-4 河床変動コンター（Case1, $2:$ 流下方向1ブロック $=1.0 \mathrm{~m}$ )

西ら8)は計算区間長が砂州の波長に大きく影響すること を示している. ハイドログラブの形状が異なる場合でも， 周期境界条件下で河床形状の波長がほぼ同様な值なのは, 波長が計算区間長の設定に応じたものであるためと考え られる. またCase3では様々な波長の河床形状が生じて 


\section{$\tau=0.0625$}

$\tau=0.17 .5$

\begin{tabular}{|l|l|l|l|l|l|l|l|l|}
\hline & & & & & & & & \\
\hline
\end{tabular}

$\tau=0.25$

\begin{tabular}{|l|l|l|l|l|l|l|l|l|l|}
\hline & & & & & & & & & \\
\hline
\end{tabular}

$\tau=0.5$

\begin{tabular}{|l|l|l|l|l|l|l|l|}
\hline & & & & & & & \\
\hline
\end{tabular}

$\tau=0.75$

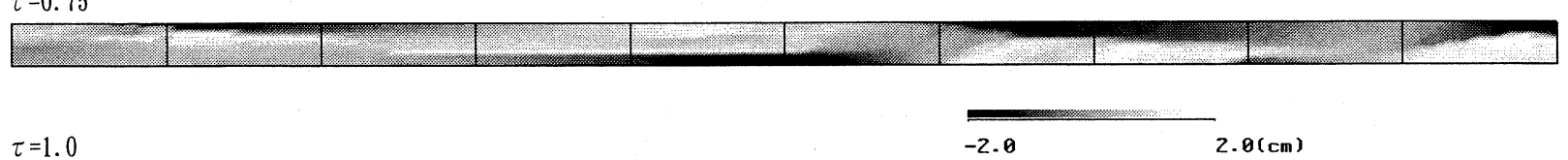

図-5＼cjkstart河床変動コンター（Case3：流下方向1ブロック=1.0m)

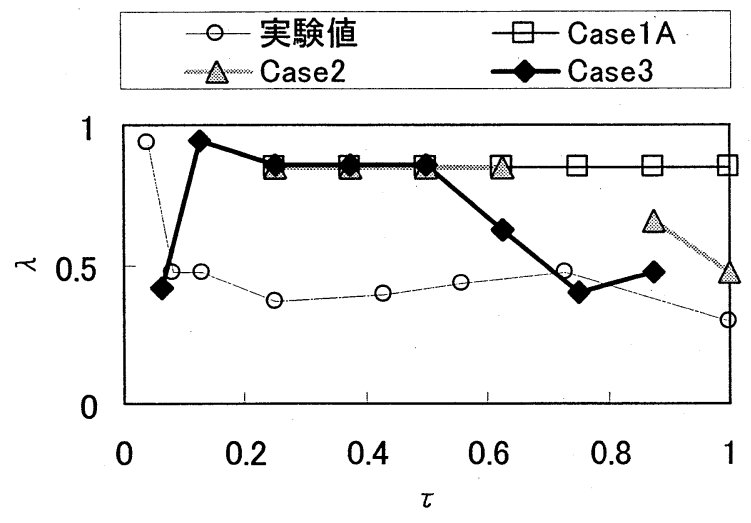

図-6 8時間通水時の実験之計算の無次元波数 $\lambda$ の比較

いるが，これは周期境界条件で拘束されていないため, 水理量に応じた河床波が発達できるためと考えられる.

以上, 各ケースについて計算を行った結果, いずれの ケースについても，全体として十分な精度は得られな かった. 特に波高の検討結果を見ると，通水開始からハ イドログラフのピーク直後までの時間帯は, 計算值は実 験值に比べ急激に河床の高低差が発達しており, 大きく 異なる結果となっている. そこで計算精度に影響する因 子についてさらに検証を行うことにする.

\section{（2） $\Delta \mathrm{t}$ と流砂の境界条件が流れに及ぼす影響の考察}

計算時間刻み $\Delta \mathrm{t}$ 及び流砂の周期境界条件が非定常流 れ，特にハイドログラフ上昇期に及ぼす影響について， 基礎的なテストケースで検証を行う。

計算条件を表-2にまとめる. 計算流路長は $3 \mathrm{~m}$ とし, 上流端に近い河岸付近の1メッシュに高さ1 $1 \mathrm{~mm}$ のマウン ドを設定している. また上下流端では周期境界条件，八

表-2 テストケースの計算条件
\begin{tabular}{|l|l|l|l|}
\hline & $\Delta t(\mathrm{sec})$ & ハイドロ & 流砂境界条件 \\
\hline RunA-1 & 0.01 & 式(12) & 周期境界 \\
\hline RunB-1 & 0.02 & $\prime$ & $"$ \\
\hline RunC-1 & 0.005 & $\prime \prime$ & $" \prime$ \\
\hline RunA-2 & 0.01 & 式(13) & " \\
\hline RunA-3 & 0.01 & 式(12) & 非周期境界 \\
\hline
\end{tabular}

イドログラフは継続時間2時間とし, 式(12)及び式(13)で 与えるものとする.

$$
\begin{aligned}
D_{0} & =\left\{\begin{array}{cc}
1.0+2.0 \times \tau & (\tau \leq 0.5) \\
1.0+2.0 \times(1.0-\tau) & (\tau \geq 0.5)
\end{array}\right. \\
D_{0} & =\left\{\begin{array}{cc}
1.0+4.0 \times \tau & (\tau \leq 0.5) \\
1.0+4.0 \times(1.0-\tau) & (\tau \geq 0.5)
\end{array}\right.
\end{aligned}
$$

ここで $\tau:$ ハイドログラフの継続時間 $T$ で無次元化し た時間 $(\tau=t / T)$.

，上下流境界条件は前述した式(7)〜(10)で与える. また 流砂の境界条件は, 周期境界条件を設定(RunA-3以外)の 場合と, 上下流で動的平衡条件設定のケース(RunA-3)を 比較する.

計算結果の $\Delta z_{\text {max }}$ を図-7に示す. いずれのケースと も, $\mathrm{t}=2400$ 秒以前は $\Delta \mathrm{z}_{\text {max }}$ はほとんど増加していない. CaseA-1，B-1，C-1を比べると， $\Delta \mathrm{z}_{\max }$ が急増する時刻 はRunC-1以外ではハイドロのピーク前の $\mathrm{t}=3000$ 秒である. 一方, RunC-1ではピーク後の $\mathrm{t}=3900$ 秒で急上昇してい る. すなわち $\Delta \mathrm{t}$ が小さいと, 同じハイドログラフでも 河床材料の移動開始時刻が遅くなる. またハイドログラ フの傾きが急であるCaseA-2は, CaseA-1に比べ $\Delta z_{\text {max }}$ の最大值が大きいとともに, 早くピークに到達している. 


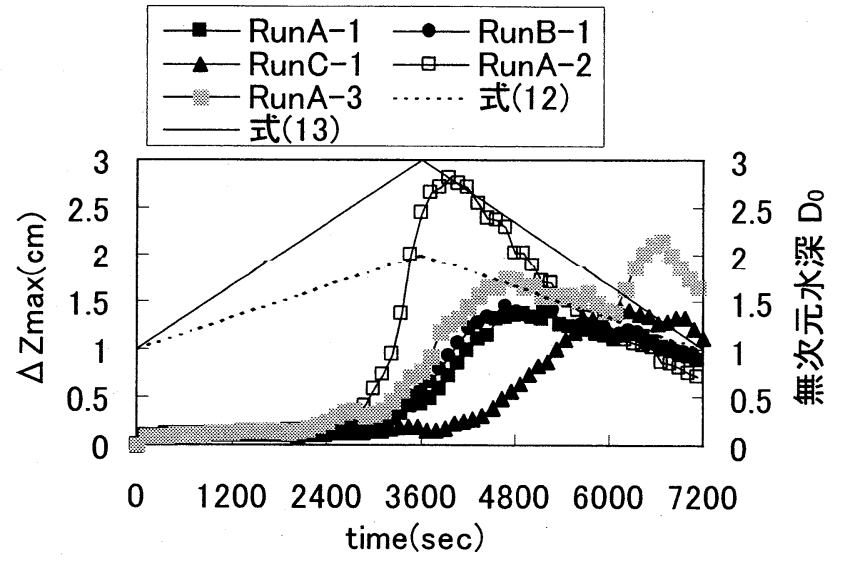

図-7 $\Delta z_{\max }$ の時間変化

また流砂量に周期境界条件を設定しなかったCaseA-3は, 他のケースと異なり $\Delta \mathrm{z}_{\text {max }}$ のピークが2つ存在している. 計算開始後しばらくは河床高がほとんど変動しない原 因としては，初期は流れの擾乱が計算領域全体に伝播し ておらず，実現象よりも流れの微小な変動が少なく計算 されている可能性が考えられる. また流砂量境界条件で あるが，非定常流れでは上流からの流入量と下流からの 流出量は異なると考えられるので，周期境界条件はこの ケースにはなじまない方法といえる.

\section{5. 結論}

非定常流下での砂州の挙動について, 非定常2次元平 面計算を行った. 結果の概要は以下のとおりである.

(1)周期境界条件を設定して行った計算では, 周期的な河 床形状が水路全体に形成された. また下流自由端で計 算を行った場合，計算区間長による制約を受けないた め様々な波長の河床波が形成された.

(2)通水開始後，周期境界条件，下流自由端を問わず，河 床形状の波高については, 最大值はすべての計算条件 で計算值が実験值を大きく上回る結果となった．特に
水位上昇期の波高は急激に増加しており，ハイドログ ラフの増減傾向とほぼ一致して変化している. 実験值 では時間とともに波高は増加しているが, 計算値とは これとは異なる傾向となった。

(3)非定常計算に影響を及ぼす因子として, 時間刻み $\Delta t$ 及び流砂境界条件を検証した. その結果，この2つの 条件は波高の変化や最大值, 河床形状の変化開始時刻 に影響していることが示された.

本論では計算值は実験結果を十分に再現していないも のの, 非定常流下でのハイドログラフ立ち上がり期を適 切に計算することが計算精度の向上につながる可能性が 示された. 今後計算モデルにおける流れの非定常効果の 再現性についてさらに検討し，計算モデルの精度向上を 目指す.

\section{参考文献}

1)黑木幹男・岸力 : 中規模河床形態の領域区分に関する理論的 研究，土木学会論文集，第342号，pp.87-96, 1984.

2)清水康行 : 沖積河川における流れと河床変動の予測手法に関 する研究，北海道開発局開発土木研究所報告，第93号， 1991.

3)Tubino,M. Growth of alternate bars in unsteady flow, Water Resource Research, Vol.27, No.1, pp37-52, 1991.

4)三輪浩, 池田香織, 谷和憲: 正弦波状流量变化による交互砂 州の発達・变形過程, 土木学会第55回年次学術講演会概要集 第2部, pp.540-541， 2000.

5)渡邊康玄, Tubino, M., Zollezi, G : 掃流砂により形成される 交互砂州の非定常流下での挙動, 北海道開発土木研究所月報, No.576, pp.4-12, 2001.

6)清水康行 : 連続床止工を有する複断面河道における流れと河 床変動の計算, 水工学論文集, 第43巻, pp.683-688, 1999.

7)Shimizu,Y. and Itakura,T.: Calculation of flow and bed deformation with a general non-orthogonal coordinate system, Proc. of XXIV IAHR Congress, Madrid, Spain, C-2, pp.41-48, 1991.

8)中西哲, 松山洋平, 黒木幹男, 板倉忠興 : 水路長が交互砂州 形状に与える影響の研究, 第56回年次学術講演会概要集(2), pp.174-175, 2001.

（2001.10.1受付） 